\title{
Integration of Islamic Input in Medical Curriculum - Universiti Sains Islam Malaysia (USIM) Experience
}

\author{
Jamilah Ja, Ahmad Najib Aa, Dzulkhairi MRª, Ariff $\mathrm{HO}^{\mathrm{b}}$, Nasri Ismail NMª \\ aFaculty of Medicine and Health Sciences, Universiti Sains Islam Malaysia, Jalan Pandan Utama Pandan Indah, \\ 55100 Kuala Lumpur. \\ ${ }^{b}$ Kulliyyah of Medicine, International Islamic University Malaysia, Bandar Indera Mahkota, 25200 Kuantan, \\ Pahang.
}

\begin{abstract}
Muslim doctors are those qualified doctors who practise their professional knowledge and skills in line with Islam and upholds the highest standards of ethical and professional behaviour. The medical curriculum of the Faculty of Medicine and Health Sciences of Universiti Sains Islam Malaysia (USIM) was designed with the integration of Islamic input which aims at producing doctors who are able to practise medicine that is integrated with Islamic, moral and ethical values. Halaqah Studies and Fundamental Islamic Knowledge (FIK) courses such as History of Medicine in Islam, Science and Medicine in Quran and Sunnah, Akhlak and Tasawuf, Islamic Jurisprudence and Medical Ethics and Fiqh Issues are taught to students during the pre-clinical and clinical phases. Memorization of selected Quranic verses throughout the programme aim to get the students to apply the verses of the al-Quran into practice in everyday life and especially in their clinical practice. Islamic values are emphasised during doctor-patient interactions in all clinical postings. Islamic knowledge and values integrated in the curriculum are assessed in written and clinical examinations. The outcome of the integration of the Naqli component in the medical curriculum has been demonstrated positively by the students in the patient management problems and clinical consultations. Studies on the outcome of the integrated Islamic input in the medical curriculum among the clinical students and graduates are being carried out.
\end{abstract}

KEYWORDS: Medical curriculum, Islamic input, integration, Naqli

\section{INTRODUCTION}

Good Muslim doctors are those qualified doctors who practise their professional knowledge and skills in line with Islam, upholds the highest standards of ethical and professional behaviour and at the same time observe all their religious duties. ${ }^{1}$

A Muslim doctor is different from other non-Muslim doctors. A good Muslim doctor should always keep pure his intention and the attainment of Allah's pleasure should be the sole objective of his life. ${ }^{2}$ With regards to medical practice, the Muslim doctor is bound by professional ethics plus his Islamic

Corresponding author:

Prof Madya Dr Jamilah Jamaludin,

Faculty of Medicine and Health Sciences,

Universiti Sains

Islam Malaysia, Jalan Pandan Utama Pandan Indah,

55100 Kuala Lumpur.

Tel: $+603-42892473$

Fax: +603-42892447

Email address: jamilah@usim.edu.my directives issuing from his belief. ${ }^{3}$ As a Muslim, the medical doctor should follow Islamic teachings and is God-fearing and God-concious (taqwa). The doctor should follow professional etiquette (adab) and ethics (akhlak). ${ }^{4}$ Muslim medical doctors meet greater responsibilities compared to other non-Muslim doctors. Muslim doctors are confronted frequently with questions concerning controversial problematic issues: e.g.,plastic surgery, birth control, abortions, etc. Thus, the Muslim doctor's profession is undoubtedly a great responsibility. ${ }^{3}$

A medical curriculum which integrates Islamic input is one way to fulfil the needs of Muslim doctors. Islamic, moral and ethical values must be incorporated in all teaching-learning activities especially during the preclinical and clinical training. Integrating Islamic input in the medical curriculum is being practised in several medical schools in Malaysia and overseas such as Indonesia, Brunei, and some other countries in the Middle East.

In Malaysia, the International Islamic University of Malaysia (IIUM) was the first to integrate Islamic values into the medical curriculum. The curriculum integrates Islamic values and Islamic law in the teaching and practice of medicine. ${ }^{5}$ The Islamic input topics are integrated throughout the 5-year programme. 
Islamization of the curriculum are carried out through integration of its teachers (teacher of medicine also teaches Islamic values), the teaching materials (Islamic values and law related to medical knowledge), and assessments (questions on Islam included in the examinations).

Universiti Sains Islam Malaysia (USIM) the $12^{\text {th }}$ public university in Malaysia is a young university in the country that aspires to transform and create value for country, Ummah and humanity by integrating Naqli (revealed) and Aqli (humanity) knowledge. All study programmes offered at USIM represent the true blend of the Naqli and Aqli based knowledge, in parallel with the philosophy of the university. This paper reports the experience of USIM in designing a medical curriculum that is integrated with Islamic input in its effort to inculcate Islamic values among the clinical students and graduates.

\section{THE MEDICAL PROGRAMME OF USIM}

The medical programme of the Faculty of Medicine and Health Sciences, Universiti Sains Islam Malaysia (USIM) was designed based on the philosophy of the university. The programme spans over 6 years ( 3 years of preclinical and 3 years of clinical) as compared to other medical programmes in the country. Thus a total of 7 years including 1 -year Tamhidi programme as foundation year allows students to acquire Islamic knowledge as well as for effective inculcation of Islamic values.

\section{Islamic input}

Knowledge can be divided into Naqli and Aqli, based on its sources. Naqli knowledge refers to knowledge which is being transmitted through the Al-Quran and Hadith. The other branch of knowledge is based on intellect. ${ }^{6}$ Islamic input or the Naqli component was integrated in the curriculum from the very beginning of the programme which started its inception in 2005. The Islamic input is taught either through specific Islamic courses or integrated in the teaching and learning in various core university, faculty and programme courses throughout the 6-year programme. One of the courses which provide Islamic input is Halaqah Studies, which is a compulsory university course. This course, which is unique to USIM, exposes students to the techniques of analyzing Islamic classical texts (turath) and applying it in their respective fields of specializations. The Islamic texts studied include Tafsir Jalalain, Tafsir Ibnu Kathir, al-Minhaj syarh an-Nawawi ala sohih Muslim, Fathul Bari syarh sohih Bukhari, and Ihya' 'Ulum al-Din. The course is conducted weekly for one semester in year 1 through tutorials, discussions and presentations by students supervised by lecturers from the Centre of Core Studies in Islamic studies from the main campus. The rules of ablution, prayer of the sick and fasting are covered in this course. This knowledge is important for students in order to help patients solve practical problems related to the pillars of Islam. Besides the study of the classical texts, students have to participate in workshops in management of the deceased and animal slaughtering. These workshops aim to prepare the students of the social responsibilities to the society and nurture leadership qualities.

A holistic curriculum must include the core Islamic references, history of Islamic medicine, contribution of Islamic scholars in research and development of medical knowledge and expertise as well as health guidelines from the Quran and the Sunnah of the Prophet. $^{7} \quad$ Fundamental Islamic Knowledge (FIK) courses are also being integrated in the medical curriculum. These courses are compulsory faculty courses. The aim of the FIK courses is to prepare the students for the knowledge in Islamic principles and values which serve as guidance in decision making in their profession as medical practitioners. History of medicine in Islam is a course which exposes the students to history of Islamic medicine as well as to highlight the contributions of Islamic scholars and doctors in various medical disciplines. In Akhlak and Tasawuf course, the role of tasawuf as a method of cleansing the heart (tazkiyyah an nafs) and replacing wrong-doings (mazmumah) with good deeds (mahmudah) are emphasised. In Science and Medicine in Quran and Sunnah course, students learn selected verses and hadiths related to the creation of the universe, creation of man, religious obligations, nutrition and health. Islamic jurisprudence is another FIK course which is introduced in the fifth year. This course exposes the students to the main sources of hukum, maqasid al-syariah and qawaid al-syariah and application of the methodology of derivation of alhukum into medical practice. Application of Islamic legal obligations in cases of illness is studied in the final year. Students participate in seminars, debates and role play sessions on various issues on ethics and figh in relation to the current practice of medicine. Examples of topics discussed in the seminar and debate include termination of pregnancy, organ donation, euthanasia, assisted reproductive technology, cosmetic surgery and non-halal materials in medicine. In this course students are expected to demonstrate the ability to articulate the Islamic values on medical ethics and apply ethical principles in making decisions and solve problems.

Memorization of Quranic verses (MOQ) courses are also compulsory faculty courses. MOQ courses are carried out throughout the programme which aim to get students apply the verses of the al-Quran into practice in everyday life and especially during their clinical practice. The students are expected to memorize selected surah specified for each semester, which include all surah in Chapters 29 and 30 and several selected surah such as Surah Yasin, Surah Al Rahman, Surah Al Waqiah and Surah al Kahfi. Recitation of the memorized Quranic verses is done individually in the presence of the Quran teacher. Memorisation of Quranic verses is being assessed as a written examination at the end of the session.

The programme courses such as basic medical 
courses (e.g. Anatomy, Physiology, Behavioural Science, Microbiology) and clinical courses also integrate Islamic input in certain relevant topics. Examples of Islamic input integrated in the programme courses are physiology of fasting, management of stress, leadership quality, infection control, family planning from Islamic perspective, lactation and nutrition. Thus Islamic input is integrated throughout the 6-year programme, during both preclinical and clinical phases.

\section{Islamic Input Integrated during the Clinical Years}

Islamic values are also incorporated during the clinical and community health postings. The clinical years are the most vital parts in medical school whereby students get the real life experience in learning and implementing what they learn during the pre-clinical years. As compared to the typical clinical teachings in other medical schools, Islamic approach is brought into the teaching methodology. A special lecture on Medical Ethics is given at the beginning of the clinical phase with emphasis on ethics and legal aspects of medical practice. Demonstration of professionalism in the proper ethical manner in line with Islamic values is being emphasised frequently and made as one of the learning outcomes of all clinical postings.

Students are expected to personally approach the patients and acquire as much information as they can related to the disease. Students are taught to approach a Muslim patient with salam and smile. During history taking, students are trained to explore the patients' spiritual status by asking questions other than those related to the patient's disease. Examples of such questions are 'whether the disease that they are suffering has anything to do with their relationship to God and how religious practices could be helpful to alleviate their sorrow and sadness during their illness. It is compulsory for students to ask patients regarding the solah practice; how the disease affect their daily solah practice and the difficulties they have to face to perform solah. Students are expected to teach patients on methods of praying during illness, on bed, on chair or even without water for ablution. The endpoint of this teaching process is to emphasize to the patients as well as the students on the importance of the daily prayers in helping to speeding up recovery and make us closer to God.

History taking is not complete without a thorough physical examination. Asking patient's permission to examine is the critical point in the process. Examination of a different gender is prohibited unless students are accompanied by a chaperone. As Muslims, students are taught to pronounce 'Bismillah' just before inspecting and touching the patients. Covering the aurah and patients' modesty is a priority while examining the patients. Failing to do so will affect the students' assessment.

Becoming a Muslim doctor is not only about prescribing medications or treatment. A holistic approach on treating patients are taught to the students, so that the disease should not be treated solely as a subject but to be managed as a whole from all perspectives for the patient betterness. Other than teaching the modern medications to prescribe or treatment to carry out, we believe that Prophetic approach in treating diseases may also be helpful to complement the modern treatment. Students have been taught verses of the Al-Quran and authentic hadiths of the Prophet Muhammad sallahu alaihi wasallam about health and diseases. They are expected to apply what they have learnt to the patients to complement the modern medication. This practice will indirectly educate the students and patients that healing does not only depend on drugs but also prayers and God's will.

\section{Teaching Learning Activities}

The Islamic courses are conducted by experts of the various disciplines from USIM or other institutions or qualified freelance teachers who are employed as part-time lecturers. The courses are conducted either in Arabic or English. Fiqh issues and ethics in medicine is a two-week course conducted in the final year. In addition to special lectures on medical law and medical ethics by invited lecturers, students actively participate in the form of seminars, debates, role play sessions and discussions. Students' participation is being assessed by a panel of assessors which includes a lecturer from the Faculty of Syariah and Law from the main campus.

Workshop on the management of the deceased is made compulsory for all students. The workshop includes both the theory and the practical of funeral rites, acts to be done after a person's death, manners of cleansing the body and the kafan, (the obligatory act of shrouding the entire body), how to perform janazah prayer and other burial rites-related issues. Workshop on the animal slaughtering is conducted with the cooperation of the committee members of the nearby mosque. The workshop provides opportunity to the students to perform slaughtering of animals the Islamic way as well as to instill social responsibility among these future leaders of the Ummah.

All lecturers are made aware of the implementation of Islamic input in the medical programme. This is being emphasised during academic workshops as well as during departmental and faculty meetings which are held regularly. Seminars on rukhsah ibadah and figh issues, annual health seminars with Islamic input, as well as faculty talks on medical ethics and medical law, are among activities which aim to educate the academic staff on these matters.

\section{The students}

The medical students of USIM are selected among those who have interest to do medicine and successfully achieved the specified criteria in the examination at the end of a one-year matriculation (Tamhidi) 
programme. Students who enter the Tamhidi programme come from various religious schools in the country with good passes in Advanced / CommunicationArabic and Islamic Studies apart from the science subjects. With good foundation in basic Islamic teachings and Arabic language during the secondary education, it is much easier to learn the Islamic knowledge courses including the memorization of Quranic verses.

\section{Assessment}

Knowledge on the Islamic courses and Islamic ethical values are assessed in both written and clinical examinations. Assignment on selected topics and essay questions are prepared by the lecturers involved in the teaching of the courses. Marks are given for student-centred activities which contribute to the summative assessment. Apart from that, objective assessments of students' Islamic approach are tested during the Patient Management Problem questions in the end of clinical posting examinations. Several clinical scenarios are presented and students are expected to answer based on Islamic input which are taught during their clinical postings. Students are also expected to include Islamic perspective of their holistic approach of management in their case write-ups as well as in their reports on Special Study Modules (SSM). In the long case clinical examination for end of clinical posting and the professional examinations, excellent marks is rewarded to students who are able to suggest holistic management with Islamic perspective. A pass in all Islamic courses is also a requirement for award of the medical degree.

\section{OUTCOME OF THE CURRICULUM}

In general, medical students of USIM have acquired Islamic knowledge through the incorporation of Islamic courses in the medical curriculum. This is demonstrated by the use of certain Hadiths and Quranic verses during presentations in seminars and debates in Medical Ethics and Fiqh Issues course and clinical postings as well as in their SSM reports. Relevant Hadith and Quranic verses are also mentioned in answering examination questions relating holistic approach in management of cases in patient management problems. Islamic approach in management of cases are also evident in case writeups and objectively-structured clinical examination (OSCE). Acceptance (redha), sabr, advise on solah and rukhsah, zikr, tayammum and relating cleanliness to Islam are some of the answers mentioned in the patient management problem.

\section{DISCUSSION}

Integrating Naqli courses in the medical curriculum in the entire six-year programme has been successfully implemented and shows a positive impact on the students as shown by their approach to management of cases. The success is attributed to the unique design of the holistic curriculum, constant reminder by the founding Dean and strong awareness of the academic staff of the objective of the establishment of the faculty. Ethics and Islamic values are constantly being emphasised at the beginning of clinical postings and reinforced during the clinical sessions by the lecturers. The implementation is made easier as the students themselves have a prior knowledge in Islamic knowledge and Arabic language.

\section{FUTURE PLANS}

The Faculty has produced four batches of graduates to serve the community. A review of the Islamic input has recently been done based on the feedback by the alumni as well as the university. A research project to explore the perception of students and graduates on the Islamic input of the medical programme is being carried out to determine their level of knowledge, attitude and practice of Islamic input as well as the impact of these on personal and professional development. Results of the study would be useful to further equip the students with Islamic values and to improve the current medical curriculum. Training of the academic staff in Islamic knowledge would further provide great impact on the implementation of the Islamic integrated curriculum since God-fearing medical teacher is a role model for students.

\section{CONCLUSION}

Integration of Islamic input in the medical curriculum of USIM is unique and has shown positive results. Inculcation of Islamic values, professional conduct and ethics during all the teaching and learning activities contributes to producing good Muslim doctors who are expected to practise their professional knowledge and skills in line with Islam. Thus Islamic input in medical curriculum is a must in order to achieve the objective of the medical programme that is to produce graduates who are knowledgeable, disciplined and devout.

\section{ACKNOWLEDGEMENT}

The authors would like to thank Universiti Sains Islam Malaysia for granting Administrative Grant PPP/PSK/ $\mathrm{STH} / 30 / 15612$ to conduct research on Islamic input in medical curriculum, its outcome and recommendations.

\section{REFERENCES}

1. Kasule $\mathrm{OH}$. Muslim physician education: Indonesian experience and new challenges. [online]. Available at: www. http:// omarkasule-04.tripod.com/id955. Accessed April 15, 2014.

2. Iqbal MK. Medical ethics: An Islamic Perspective. Islamabad: Institute of Policy Studies, 2013.

3. Abu-Saud M. The Role of a Muslim Doctor. In: Shahid Athar (Ed): Islamic Medicine. Amazon co.uk. 2014.

4. Kasule $\mathrm{OH}$. Islamization Of The Curriculum: The 
Islamic Input In The Medical Curriculum (IIMC) At The Kulliyah Of Medicine. [online]. 2008.

Available at: http://omarkasule-04.tripod.com/ id1141.html Accessed April 15, 2014.

5. Kasule $\mathrm{OH} . \mathrm{A} 13$-year experience of integrating Islamic values in the medical curriculum in SouthEast Asia: FIMA Year Book, 2009:1-28.

6. Alavi SMZ. Muslim educational thought in the in the middle ages. New Delhi: Atlantic Publishers and Distributers, 1988.

7. Iqbal MK. Ethical issues related to medical education in the light of Islamic principles. FIMA Year Book, 2009:83-98. 